Article

\title{
Thymoquinone, the Most Prominent Constituent of Nigella Sativa, Attenuates Liver Damage in Streptozotocin-Induced Diabetic Rats via Regulation of Oxidative Stress, Inflammation and Cyclooxygenase-2 Protein Expression
}

\author{
Saleh A. Almatroodi ${ }^{1}\left(\mathbb{D}\right.$, Abdullah M. Alnuqaydan $^{2}$, Mohammed A. Alsahli ${ }^{1}$, Amjad Ali Khan ${ }^{3}(\mathbb{D}$ \\ and Arshad Husain Rahmani ${ }^{1, *}$ \\ 1 Department of Medical Laboratories, College of Applied Medical Sciences, Qassim University, \\ Buraydah 51452, Saudi Arabia; smtrody@qu.edu.sa (S.A.A.); shly@qu.edu.sa (M.A.A.) \\ 2 Department of Medical Biotechnology, College of Applied Medical Sciences, Qassim University, \\ Buraydah 51452, Saudi Arabia; ami.alnuqaydan@qu.edu.sa \\ 3 Department of Basic Health Sciences, College of Applied Medical Sciences, Qassim University, \\ Buraydah 51452, Saudi Arabia; akhan@qu.edu.sa \\ * Correspondence: ah.rahmani@qu.edu.sa
}

Citation: Almatroodi, S.A.; Alnuqaydan, A.M.; Alsahli, M.A.; Khan, A.A.; Rahmani, A.H. Thymoquinone, the Most Prominent Constituent of Nigella Sativa, Attenuates Liver Damage in Streptozotocin-Induced Diabetic Rats via Regulation of Oxidative Stress, Inflammation and Cyclooxygenase-2 Protein Expression. Appl. Sci. 2021, 11, 3223. https://doi.org/ 10.3390/app11073223

Academic Editors: Bruno Tirillini and Wojciech Kolanowski

Received: 27 February 2021

Accepted: 1 April 2021

Published: 3 April 2021

Publisher's Note: MDPI stays neutral with regard to jurisdictional claims in published maps and institutional affiliations.

Copyright: (c) 2021 by the authors. Licensee MDPI, Basel, Switzerland. This article is an open access article distributed under the terms and conditions of the Creative Commons Attribution (CC BY) license (https:// creativecommons.org/licenses/by/ $4.0 /)$.

\begin{abstract}
Diabetes mellitus (DM) is a multifaceted metabolic disorder that results in dysfunction and failure of various organs. The present study aimed to evaluate the role of Thymoquinone (TQ), on antidiabetic, oxidative stress, and anti-inflammatory activities in streptozotocin (STZ)induced $(55 \mathrm{mg} / \mathrm{kg}$ b.w) diabetic rats. TQ was orally given for 8 consecutive weeks at dose of $150 \mathrm{mg} / \mathrm{kg}$ b.w. The blood glucose, insulin, total cholesterol, triglycerides, liver function enzymes, high density lipoprotein (HDL)-cholesterol, and low-density lipoprotein (LDL)-cholesterol levels were measured accordingly in control, diabetes control (DC), and TQ-treatment groups. These experiments confirmed that TQ conserves the insulin level $(0.4 \mathrm{ng} / \mathrm{mL}$ vs. $0.23 \mathrm{ng} / \mathrm{mL})$, fasting blood glucose (146 $\pm 7 \mathrm{mg} / \mathrm{dL}$ vs. $225 \pm 5 \mathrm{mg} / \mathrm{dL})$, and HbA1c (7.5\% vs. 10.6\%) quite considerably as compared to DC animals. Our results also confirmed that TQ treatment conserves the body weight and lipid profile significantly in STZ-treated animals as compared to the DC group. Moreover, the antioxidant enzymes (GSH, SOD, GST, and CAT) levels decreased, liver function enzymes (ALT, AST, and ALP), lipid peroxidation and inflammatory markers (TNF- $\alpha$, CRP, IL-1 $\beta$, IL-6) increased by STZ treatment, that is significantly restored after TQ treatment. As compared to untreated animals, TQ restored the hepatocytes architectural changes and collagen fibers and cox-2 protein expression in liver tissues as evaluated by hematoxylin and eosin, Masson's trichrome, and immunohistochemistry staining. Taken together, all these findings indicated that TQ ameliorates glucose level and lipid metabolism. It restores liver function, antioxidant enzymes, anti-inflammatory markers, and maintains hepatocytes architecture in STZ-induced diabetes mellitus rats. Here, in this study, we have demonstrated for the first time the role of TQ in the reduction of the expression of cyclooxygenase- 2 and fibrosis formation in diabetic rats. Based on the findings, the study suggests that TQ is a novel natural drug with a wide range of clinical applications including the management of diabetes mellitus.
\end{abstract}

Keywords: thymoquinone; anti-diabetic; oxidative stress; inflammatory markers; immunohistochemistry; streptozotocin

\section{Introduction}

Diabetes mellitus (DM) has been increasing at an alarming rate around the world, which is a serious, chronic, and multifaceted metabolic disorder of numerous etiologies with grave consequences [1]. The population with DM is increasing rapidly and it is predicted to reach almost 600 million by the year 2035 [2]. The severe effects of diabetes mellitus include prolonged damage, failure, and dysfunction of different vital organs [3]. 
Type 2 diabetes is the most predominant form of diabetes as it accounts for almost $90 \%$ of total diabetes cases [4]. The pancreatic $\beta$-cell function is diminished in type II diabetes and insulin resistance occurs in hepatic as well as peripheral tissues, causing an uncontrolled hepatic glucose level and altered uptake of peripheral glucose [5]. The complications of DM have been recognized for a long time, but detailed knowledge of its main causes and its proper treatments were not fully known till date [6]. More than fifty percent of cases of $\mathrm{DM}$ are undiagnosed globally because such diseased cases are ignorant of their condition and maximum cases are from low or middle-income countries [7].

Different lines of treatments have been tried for the prevention of DM including effective hypoglycemic drugs. Theses hypoglycemic formulations have shown serious adverse complications after long use [8]. Evidence from different studies have proven that some bioactive compounds from important medicinal plants or natural compounds from various sources ameliorate pathological conditions as they are rich source of antioxidants [9]. An advised remarkable approach is a plant-based formulation or natural compound derived from the medicinal plants or functional food, which plays an important role in the management of DM and its associated complications [10].

Nigella sativa is a well-known medicinal plant that is used for thousands of years in the treatment of various diseases. Nigella sativa and its key active component thymoquinone (TQ) have been well-reported to exert its pharmacological actions by improving important biological activities, such anti-inflammatory, immunomodulatory, antitumor, analgesic, antihypertensive, antidiabetic, antimicrobial, antioxidant, and tissue protective properties in a several types of disorders [11-16].

Based on the novel findings from previous studies, which report the vital role of TQ in diseases management, here in this study, we aimed to assess the anti-diabetic effects of TQ in STZ-induced diabetic rats. We further elaborated our findings by evaluating the antioxidant, anti-inflammatory, liver function enzymes, and hepatoprotective effects of TQ.

\section{Materials and Methods}

\subsection{Chemicals and Reagents}

Streptozotocin and thymoquinone were procured from Sigma (Missouri, USA). The liver function enzyme kits were purchased from Abcam. The antioxidant enzyme kits including (GST, CAT, SOD, and GSH), the inflammatory marker rat specific ELISA kits (TNF- $\alpha$, CRP, IL-6, and IL-1 $\beta$ ) were procured from Abcam (Abcam, Cambridge, UK). The lipid profile kits were purchased from Crescent diagnostics, Jeddah, Saudi Arabia. The staining kits (Masson trichrome and Sirius red) and Cox-2 antibody were also purchases from Abcam. All the other routine chemicals were purchased from Sigma. In addition, some chemical and reagents utilized in this study, were obtained from the local distributors of different companies in Saudi Arabia.

\subsection{Animals}

Male Albino white wistar rats weighing as $250 \pm 10$ grams, were acquired from King Saud University (KSU), Saudi Arabia (SA). The total number of animals used in this study were 32 divided randomly in 4 groups as normal control $(n=8)$, disease control $(n=8)$, positive control $(n=8)$, and thymoquinone treatment $(n=8)$. The animals were kept as such, for one week, as an acclimatization period to reduce the transportation stress, prior to the start of the experiment. They were randomly housed as 8 rats/cage and received normal rat chow and tap water ad libitum in a constant animal house environment with $22{ }^{\circ} \mathrm{C}$ temperature, relative humidity $(50 \% \pm 5)$, and a $12 \mathrm{~h} \mathrm{light/dark} \mathrm{cycle.} \mathrm{The} \mathrm{rat} \mathrm{chow}$ used was also purchased from the KSU, SA.

\section{Animal Ethics}

The animal handling protocols were performed as per the procedures given by the animal care unit of College of Applied Medical Sciences, Qassim University. The study was approved by the Laboratory Animal Ethics Committee (ethics committee no. 2019- 
2-2-I-5623) of the Qassim University. All protocols were applied to reduce the animal suffering.

\subsection{Induction of Experimental Diabetes Mellitus and Experimental Design}

All the animals were allowed to fast overnight prior to start the experiment. Diabetes was induced in rats by a single intraperitoneal (i.p.) injection of streptozotocin (STZ) (55 milligrams/kg b.w.) dissolved in freshly prepared in citrate buffer [17], except the control group animals which were injected with the same volume of buffer solution intraperitoneally. The STZ-treated animals were allowed to take glucose solution for overnight which was replaced with normal tap water onwards. After $72 \mathrm{~h}$, the glucose concentration was measured by puncturing the tail vein, in all the animals with a glucometer. The glucose concentration was measured by test strip glucometer (ACCU-CHEK, Active, Germany). The animals with blood glucose level more than $200 \mathrm{mg} / \mathrm{dl}$ were considered as diabetic and were included for the experiments. The treatments were started on day 4 after STZ injection, and this was considered day 1 for treatment and was continued for eight weeks. A total of 32 experimental rats were used to examine the anti-diabetic effect of thymoquinone on the experimental rats. The rats were divided into the four groups as:

\begin{tabular}{|c|c|c|}
\hline Group Number & Group Name & Experimental Conditions \\
\hline 1 & Normal Control (NC) & $\begin{array}{l}\text { Rats allowed to have free access to tap } \\
\text { water and a standard rat chow }\end{array}$ \\
\hline 2 & Disease control (DC) & $\begin{array}{l}\text { Diabetic rats induced by STZ (55 mg/kg } \\
\text { b.w.), serving as diabetic control [17] }\end{array}$ \\
\hline 3 & Positive control (PC) & $\begin{array}{l}\text { Animals serving as positive control, were } \\
\text { injected with STZ and Glibenclamide } \\
\qquad(5 \mathrm{mg} / \mathrm{kg} \text { b.w. })[18]\end{array}$ \\
\hline 4 & $\begin{array}{l}\text { Thymoquinone treatment } \\
\text { (STZ + TQ) }\end{array}$ & $\begin{array}{l}\text { Diabetes treatment group, STZ-induced } \\
\text { diabetic animals treated with } 50 \mathrm{mg} / \mathrm{kg} \\
\text { b.w. TQ [19] }\end{array}$ \\
\hline
\end{tabular}

In the current study, the TQ dose used is $50 \mathrm{mg} / \mathrm{kg}$ b.w. which is significantly a very low dose and this dose did not show any toxicity. The $\mathrm{LD}_{50}$ after oral ingestion has been reported as $870.9 \mathrm{mg} / \mathrm{kg}$ and $\mathrm{LD}_{50}$ values presented $100-150$ times greater than dose of TQ for its anti-inflammatory, antioxidant, and anti-cancer effects [20]. The high dose of TQ showed toxicity as rats which received oral ingestion of TQ showed transient toxicity signs. Two deaths were reported at dose of $500 \mathrm{mg} / \mathrm{kg}$ as a result of bowel obstruction complications [21]. Based on these reports, we did not include an additional TQ treatment only group.

\subsection{Body Weight Measurements}

At the start of every week, the body weights of all animals were measured and the results were analyzed accordingly.

\subsection{Blood Glucose Estimation}

The fasting blood glucose level of all the experimental animals was estimated to measure the diabetic status within each group. The blood was collected by pricking the rat tails and blood glucose levels were estimated with the help of a standard glucometer. At the end of experiment, the rats were devoid of food for overnight. The serum insulin levels were measured as per the manufacturer's instruction.

\subsection{Lipid Profile Measurement}

The lipid parameters such as total cholesterol (TC), triglycerides (TG), high-density lipoprotein (HDL) cholesterol, and low-density lipoprotein (LDL) cholesterol were esti- 
mated by using kits (Crescent diagnostics, Jeddah, KSA) and results were interpreted accordingly.

\subsection{Measurement of Liver Function Enzymes}

After blood collection in plain vials, it was allowed to clot at room temperature for $30 \mathrm{~min}$. The serum was separated by centrifugation at $3000 \times g$ for $15 \mathrm{~min}$ at room temperature. In serum, aspartate aminotransferase (AST), alanine aminotransferase (ALT), and alkaline phosphatase (ALP) was measured as per the manufacturer instruction.

\subsection{Glycosylated Haemoglobin Level}

The glycosylated hemoglobin $(\mathrm{HbA} 1 \mathrm{c})$ in the blood was measured with a little modification to the previously described method [22]. Briefly, the saline washed erythrocytes were collected and incubated at $37^{\circ} \mathrm{C}$ for $15 \mathrm{~min}$. The supernatant was discarded, then for the additional process for assessment of $\mathrm{HbA} 1 \mathrm{c}, 0.5 \mathrm{~mL}$ of saline was added and properly mixed. The contents were heated after the addition of $0.05 \mathrm{~mL}$ of aliquot and $6 \mathrm{~mL}$ of oxalate hydrochloric solution. The solution was cooled and precipitated with $3 \mathrm{~mL}$ of $40 \%$ TCA. To the $0.6 \mathrm{~mL}$ of supernatant, $0.06 \mathrm{~mL}$ of phenol and $4.0 \mathrm{~mL}$ of $\mathrm{H}_{2} \mathrm{SO}_{4}$ were added. After $30 \mathrm{~min}$, the color was developed that was measured at $480 \mathrm{~nm}$.

\subsection{Creatinine and Urea}

The creatinine and urea level in serum was measured by colorimetric assay kits according to the producer's instructions.

\subsection{Estimation of Antioxidant Enzymes Levels}

The liver tissues from each animal groups were homogenized in ice-cold TCAphosphate buffer saline (10\%). The liver homogenates were then centrifuged at $4{ }^{\circ} \mathrm{C}$ temperature at $15,000 \times g$ for $10 \mathrm{~min}$. The supernatants were obtained for the estimation of antioxidant enzymes including SOD, GST, and CAT activities and the levels of GSH. The antioxidant enzymes were estimated calorimetrically by using commercial kits (Abcam, Cambridge, UK) according to the manufacturer instructions.

\subsection{Lipid Peroxidation Levels Measurement}

The lipid peroxidation was measured spectrophotometrically by checking the concentration of thiobarbituric acid reactive product and the absorbance was measured at $534 \mathrm{~nm}$ [23].

\subsection{Measurement of Pro-Inflammatory Parameters}

An ELISA test was performed for the estimation of TNF- $\alpha, \mathrm{CRP}, \mathrm{IL}-1 \beta$, and IL-6 according to the manufacturer's protocol and results were interpreted accordingly.

\subsection{Hematoxylin and Eosin (HEE) Staining for Histological Examinations}

The liver tissues of all experimental animals were taken and washed with the normal saline and fixed with $10 \%$ formalin. The tissues were processed by using tissue processor (Leica, Germany). The paraffin wax was used to embed the tissues and $5 \mu \mathrm{m}$ thin sections were made and mounted on the polylysine coated slides. All the slides were stained with $H \& E$ and observed under light microscope by multiple magnifications to examine the tissues architecture. The entire assessment was evaluated by a pathologist in a blinded fashion.

\subsection{Masson's Trichrome Staining}

All the liver tissues were fixed in $10 \%$ phosphate-buffered formalin. The tissues were processed using automated tissue processor (Leica, Germany), then embedded in paraffin, sliced into 5- $\mu \mathrm{m}$ sections, and stained with Masson's trichrome at room temperature according to the manufacturer's instruction. All sections were evaluated and the images 
were captured under light microscopy (Olympus Corporation, Tokyo, Japan) and the result were interpreted accordingly.

\subsection{Expressional Evaluation of Cox-2 Protein}

The Cox-2 protein expression was measured through immunochemistry as per the method previously described $[24,25]$. The antigen retrieval was performed in all the tissues and the primary monoclonal antibodies Cox-2 were incubated overnight at $4{ }^{\circ} \mathrm{C}$ temperature. Biotinylated secondary antibodies (Abcam kits, Cambridge, UK) were added and incubation was performed for one hour at room temperature. Horseradish peroxidase was applied on tissues for $30 \mathrm{~min}$ at room temperature. Finally, diaminobenzidine (DAB) was used as chromogen and the sections were counterstained with hematoxylin stain. The images of sections were taken by using a digital camera, and the results were interpreted accordingly.

\subsection{Statistical Analysis}

All values were expressed as mean $\pm S D$. The statistical significance was evaluated by one-way analysis of variance (ANOVA) using SPSS. The post hoc test (Tukey test) was used to compare different groups. A value of $p<0.05$ was considered to indicate a significant difference between the animal groups.

\section{Results}

\subsection{Effect of $T Q$ on Body Weight in Experimental Groups}

The body weight of all experimental group rats was measured weekly. The body weight of all experimental animals exhibited no noticeable changes between the different groups. After 8 weeks of continuous treatment, the body weight of normal control rats gained significantly ( $260 \pm 9 \mathrm{~g}$ vs. $310 \pm 10 \mathrm{~g})$. STZ led to a significant weight loss $(205 \pm 9 \mathrm{~g})$ in the STZ-treated group (DC group) in comparison to the normal control (NC group) and rats' body weights notably augmented in diabetic rats treated with TQ $(290 \pm 10 \mathrm{~g})$ $(p<0.05)$ [Figure 1]. Supplementation of TQ to diabetic rats showed a significant lowering effect on the body weight changes as compared with diabetic rats fed with normal diet.

[a]

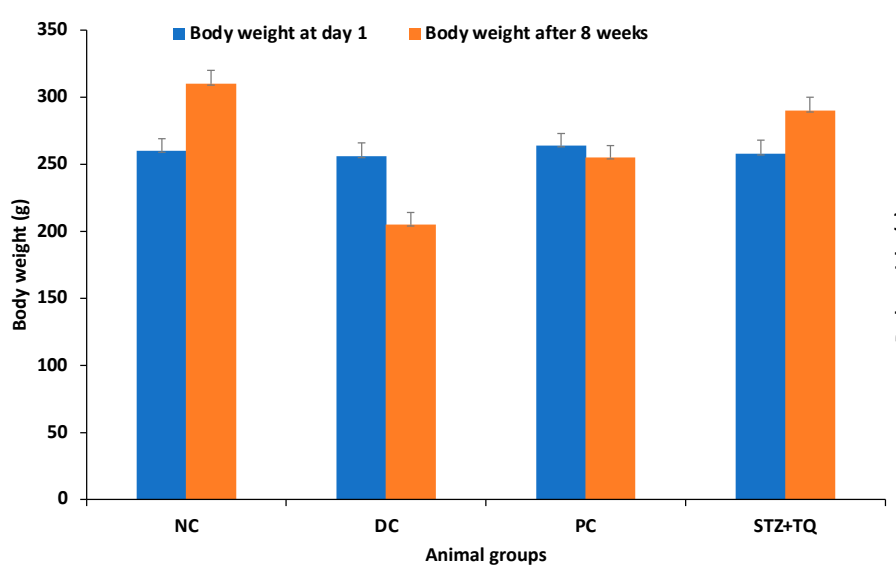

[b]

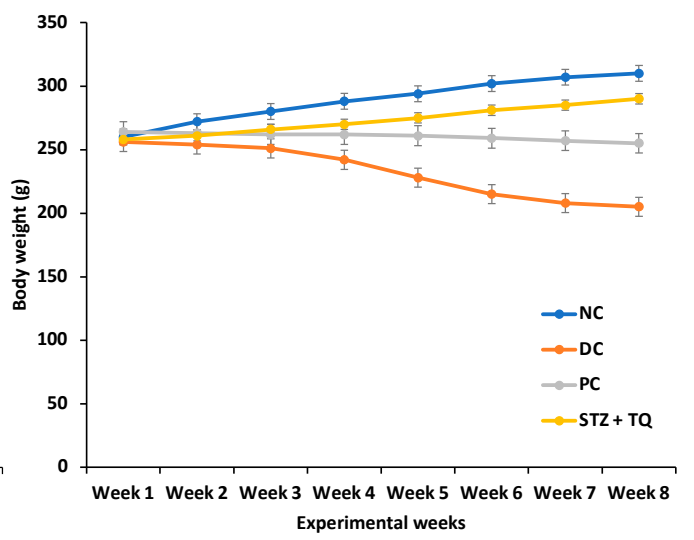

Figure 1. (a) The initial and the last body weight of different groups of rats after 8 weeks of experiment. (b) The week-wise measurement of body weight of all experimental animals from week 1 to week 8 . The animals were randomly distributed into each group ( $n=8$ per group). Data are means \pm standard error of the mean (SEM). Groups: Normal control (NC); disease control (DC) i.e., STZ-treated group; positive control (PC) animal treated with STZ and Glibenclamide; diabetic rats treated with TQ $(\mathrm{STZ}+\mathrm{TQ}) \cdot p<0.05$ (significant difference of final b.w. between DC vs. NC) $p<0.05$ (significant difference of final b.w. between DC vs. STZ + TQ). 


\subsection{Effect of TQ on Glucose-Related Parameters in STZ-Toxicated Diabetic Rats}

The blood glucose levels (fasting) in all the rats were examined weekly from week 0 to 8 during the experiment. The average fasting blood glucose in STZ-injected diabetic rats was significantly higher $(225.5 \pm 7.50 \mathrm{mg} / \mathrm{dL})$ than that in normal control rats $(94 \pm 5.30 \mathrm{mg} / \mathrm{dL})$ $(p<0.05)$ (Figure 2). After 8 weeks of continues treatment with the TQ, a decline in fasting blood glucose level in STZ-induced diabetic rats (STZ + TQ) was noticed to be $(146 \pm 6.20)$ $(\#<0.05)$ as compared to the DC group (Figure 2). These finding reveal that TQ plays a substantial role in the induction of hypoglycemic effects or recovered the hyperglycemic state near to normal in diabetic rats.
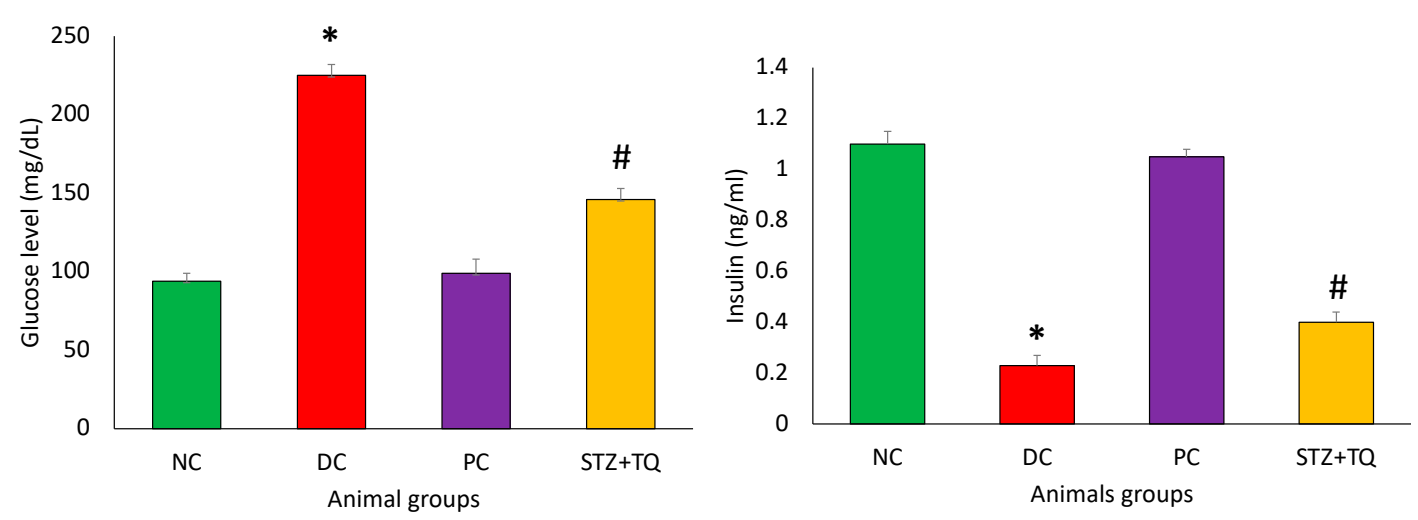

Figure 2. The level of blood glucose and insulin change in different groups of rats after 8 weeks of continues treatment. The experimental animals were evenly distributed into each group ( $n=8$ per group). Data are means \pm standard error of the mean (SEM). Groups: Normal control (NC); disease control (DC) i.e., STZ-treated group; positive control (PC) animal treated with STZ and Glibenclamide; diabetic rats treated with TQ $(\mathrm{STZ}+\mathrm{TQ}) .{ }^{*} p<0.05$ (significant different of average glucose and insulin level between DC vs. NC) ${ }^{\#} p<0.05$ (significant difference of average glucose and insulin level between DC vs. STZ + TQ).

The STZ-treated rats showed significant reduction in insulin level $(0.23 \mathrm{ng} / \mathrm{mL})$ $(p<0.05)$ as compared to normal control group rats $(1.1 \mathrm{ng} / \mathrm{mL})$. Moreover, the diabetic animals treated with TQ $(\mathrm{STZ}+\mathrm{TQ})$ showed increased serum insulin level $(0.4 \mathrm{ng} / \mathrm{mL})$ and the difference in insulin level in the STZ-treated group treated with thymoquinone was statically significant $(\#<0.05)$. These results suggest that TQ administration ameliorates STZ-induced diabetes mellitus (Figure 2).

The glycosylated hemoglobin ( $\mathrm{HbA} 1 \mathrm{c})$ level of the rats was also measured. The results confirmed that $\mathrm{HbA} 1 \mathrm{c}$ level $(10.64 \pm 1.15 \%)$ of STZ-intoxicated diabetic rats was significantly $(p<0.05)$ increased in comparison to the normal control $(5.89 \pm 0.5 \%)$. STZ-induced diabetic plus TQ-treated animals showed significantly decreased percentage of $\mathrm{HbA} 1 \mathrm{c}$ level $(7.5 \pm 0.32 \%)(p<0.05)$ and these findings demonstrated that TQ plays a vital role in decreasing the hemoglobin glycosylation level (Figure 3).

\subsection{Effect of Thymoquinone on Lipid Profile and Liver Function Enzyme Markers in STZ-Intoxicated Diabetic Rats}

The lipid profile was measured in all experimental groups. The results indicated that serum total cholesterol (TC) $(139.37 \pm 8.7 \mathrm{mg} / \mathrm{dL})$, triglycerides (TG) $(132.3 \pm 9.5 \mathrm{mg} / \mathrm{dL})$, low-density lipoprotein (LDL)-cholesterol $(102.23 \pm 8.7 \mathrm{mg} / \mathrm{dL})$ levels were significantly increased and high-density lipoprotein (HDL)-cholesterol decreased (38.6 $\pm 7.2 \mathrm{mg} / \mathrm{dL}$ ) in STZ-injected diabetic rats. The TQ treatment caused a significant reduction of TC, TG, LDL-cholesterol levels as $(117.23 \pm 4.7 \mathrm{mg} / \mathrm{dL}, 201.23 \pm 9.4 \mathrm{mg} / \mathrm{dL}, 132.3 \pm 8.7 \mathrm{mg} / \mathrm{dL})$ respectively. Moreover, the decreased serum HDL-cholesterol in diabetic rats was also upturned $(61.9 \pm 7.2 \mathrm{mg} / \mathrm{dL})$ toward the normal level after the treatment with TQ $(p<0.05)$ (Figure 4). 


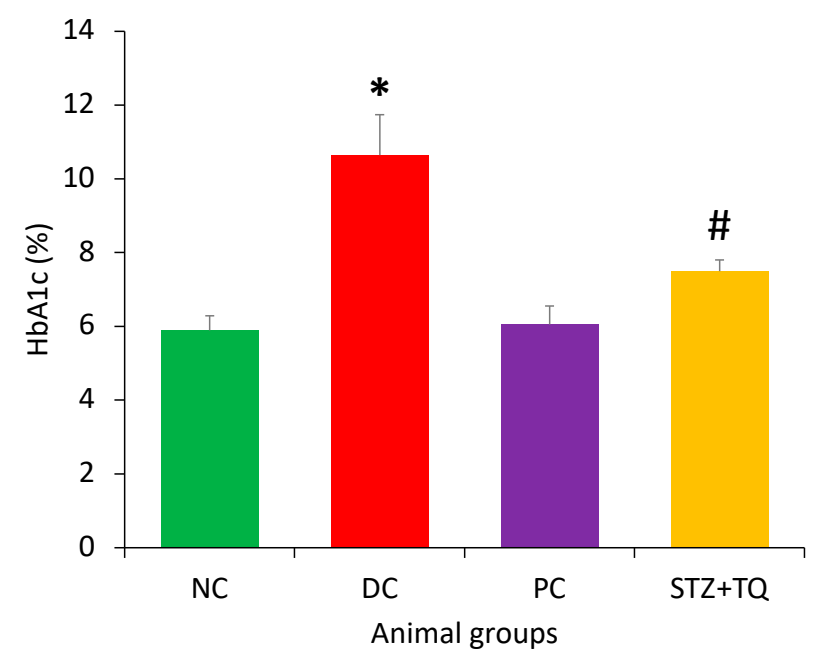

Figure 3. The percentage of $\mathrm{HbA1c}$ in different groups of rats after eight weeks of treatment. Rats were evenly divided into each group ( $n=8$ per group). Data are means \pm standard error of the mean (SEM). Groups: Normal control (NC); disease control (DC) i.e., STZ-treated group; positive control (PC) animal treated with STZ and Glibenclamide; diabetic animals treated with TQ (STZ + TQ). ${ }^{*} p<0.05$ (significant difference of HbA1c percentage between DC vs. NC), ${ }^{\#} p<0.05$ (significant difference of $\mathrm{HbA} 1 \mathrm{c}$ percentage between DC vs. STZ + TQ).
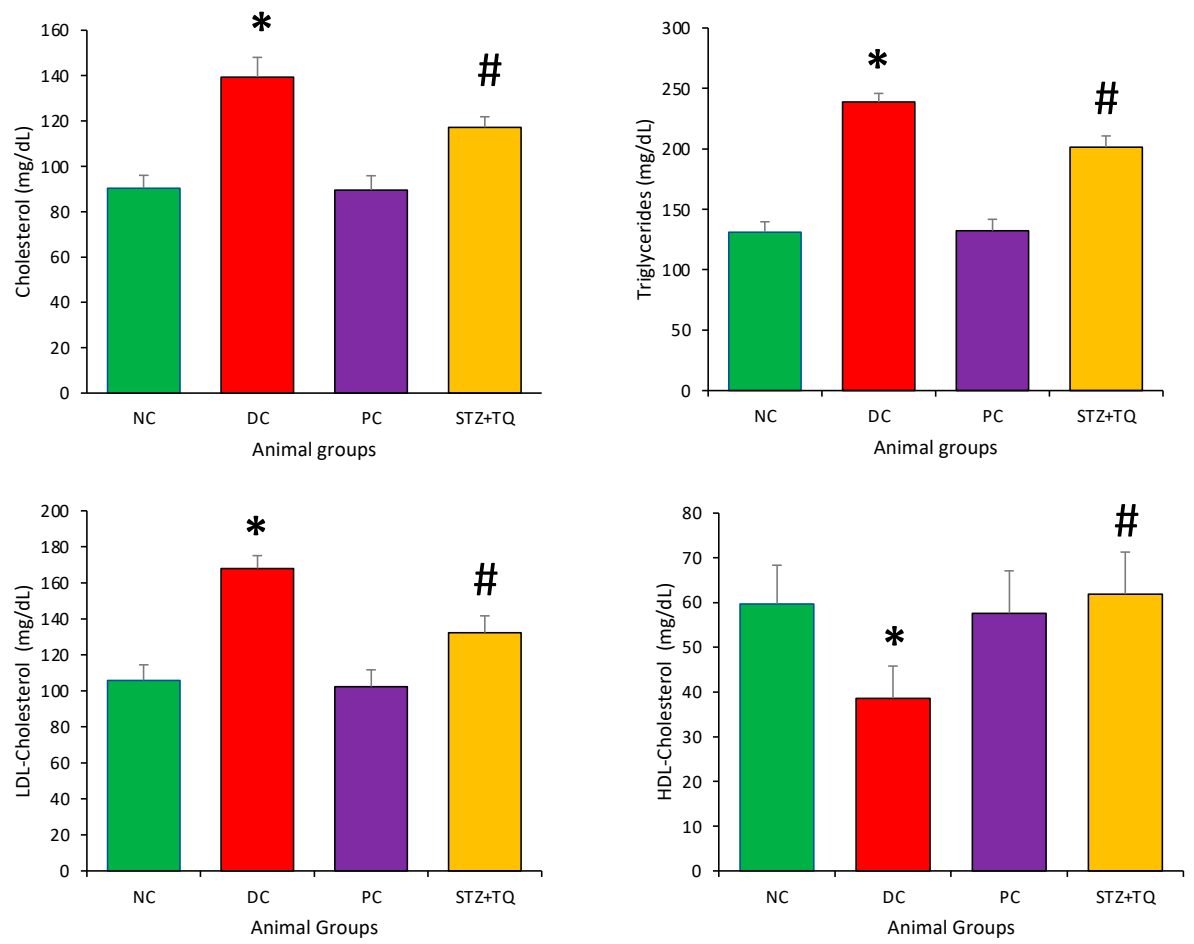

Figure 4. The lipid profile in different groups of rats after 8 weeks of follow up. Rats were uniformly divided into each group ( $n=8$ per group). Data are means \pm standard error of the mean (SEM). Groups: Normal control (NC); disease control (DC) i.e., STZ-treated group; positive control (PC) animal treated with STZ and Glibenclamide; diabetic rats exposed with TQ (STZ + TQ). ${ }^{*} p<0.05$ (significant difference of between DC vs. NC), ${ }^{\#} p<0.05$ (significant difference between DC vs. STZ + TQ).

The liver function enzymes were measured in all experimental groups. In the current study, it was noticed that STZ (55 mg/ kg b.w.)-induced diabetic rats showed significantly increased liver function enzymes like ALP (153.2 $\pm 3 \mathrm{U} / \mathrm{L})$, ALT (147.5 $\pm 9 \mathrm{U} / \mathrm{L})$, and AST 
$(194.6 \pm 3)$ in comparison to the control group $(p<0.05)$. In addition, the treatment of STZ-treated diabetic rats with TQ led to a significant reduction in levels of liver function enzymes (112.6 $\pm 9 \mathrm{U} / \mathrm{L}, 120.5 \pm 8 \mathrm{U} / \mathrm{L}, 139.3 \pm 9 \mathrm{U} / \mathrm{L})$ towards normal levels, which is evidence that TQ protects hepatocytes (Figure 5).
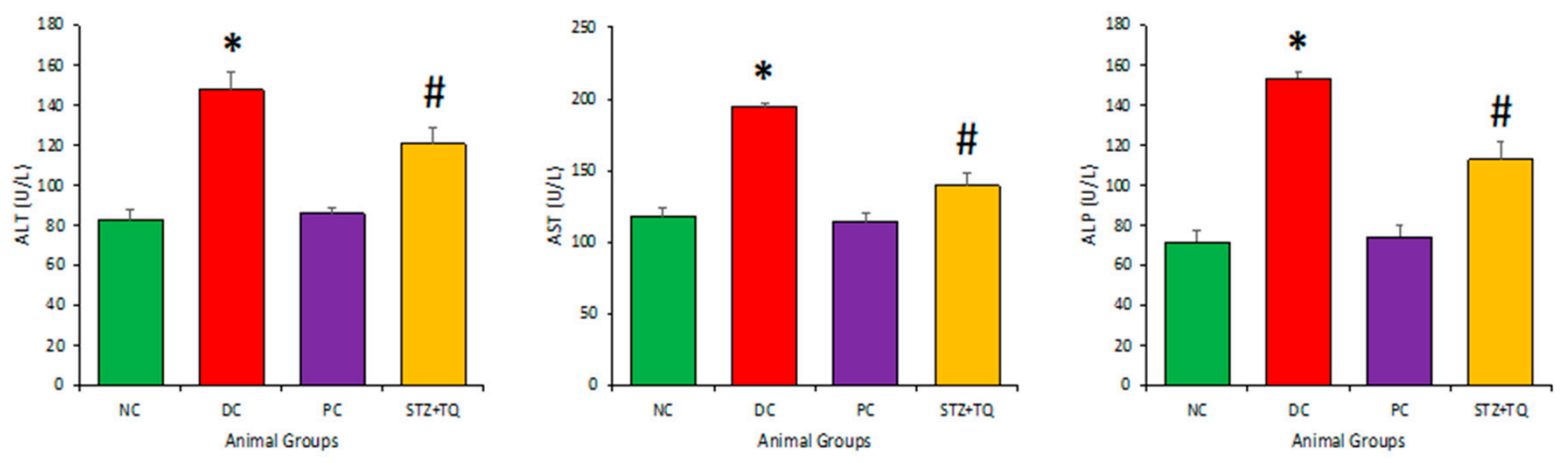

Figure 5. The liver function test profile in different groups of rats after 8 weeks of follow up. The animals were equally divided into each group ( $n=8$ per group). Data are means \pm standard error of the mean (SEM). Groups: Normal control (NC); disease control (DC) i.e., STZ-treated group; positive control (PC) animal treated with STZ and Glibenclamide; diabetic rats managed with TQ $(\mathrm{STZ}+\mathrm{TQ}) .{ }^{*} p<0.05$ (significant difference of between DC vs. NC), ${ }^{*} p<0.05$ (significant difference between DC vs. STZ + TQ).

\subsection{Effect of Thymoquinone on Antioxidant Enzyme Levels in STZ-Treated Diabetic Rats}

The antioxidant activity of TQ was analyzed by measuring the antioxidant status in liver homogenate of different groups of animals. The antioxidant status like glutathione level (GSH) and antioxidant enzyme like superoxide dismutase (SOD), Glutathione-Stransferase (GST), and catalase (CAT) activities were checked. In the current study, it was found that STZ- induced animal groups showed decreased level of antioxidant enzyme activities (SOD as $34.3 \pm 3 \mathrm{U} / \mathrm{mg}$ protein, GST as $87.9 \pm 10 \mathrm{U} / \mathrm{mg}$ protein, and CAT as $19.2 \pm 3 \mathrm{U} / \mathrm{mg}$ protein) in the hepatic tissues. Additionally, the activities these enzyme (SOD as $45.8 \pm 9 \mathrm{U} / \mathrm{mg}$ protein, GST as $152.4 \pm 9 \mathrm{U} / \mathrm{mg}$ protein and CAT as $25.6 \pm 1 \mathrm{U} / \mathrm{mg}$ protein) activities and the intensity of GSH prominently increased in the STZ + TQ group $(p<0.005)$ (Figure 6). The treatment with TQ restored the enzyme activities towards the normal value. These findings evidently show that that TQ plays a vital role as hepatoprotective against STZ-induced diabetic animals by employing its antioxidant properties.

\subsection{TQ Inhibits Lipid Peroxidation in STZ-Treated Diabetic Rats}

The higher levels of oxidative stress (ROS) induce lipid peroxidation within the membranes and the production of malondialdehyde (MDA). Liver MDA levels were significantly higher in the STZ-induced rat group $(136.3 \pm 3 \mathrm{nmol} / \mathrm{g})$ in comparison to the control animals $(95.7 \pm 6 \mathrm{nmol} / \mathrm{g})$. The MDA level decreased significantly $(p<0.05)$ in the STZ-induced rats + TQ treatment group $(96.3 \pm 4 \mathrm{nmol} / \mathrm{g})$ as compared with the diabetes control animals (Figure 7). 

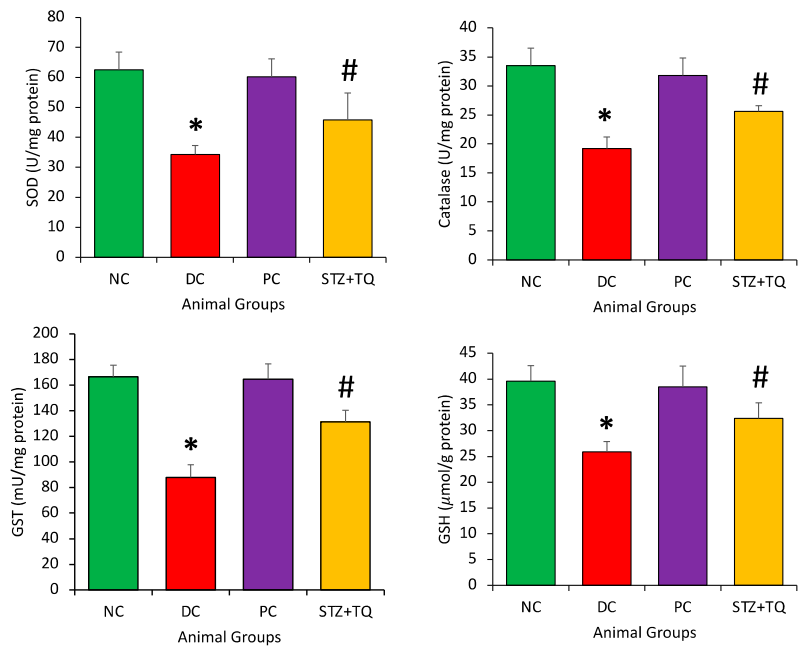

Figure 6. The antioxidant enzymes and antioxidant profile in different groups of rats after 8 weeks of follow up. The experimental animals were evenly distributed into different groups ( $n=8$ per group). Data are means \pm standard error of the mean (SEM). Groups: Normal control (NC); disease control (DC) i.e., STZ-treated group; positive control (PC) animal treated with STZ and Glibenclamide; diabetic rats treated with TQ $(\mathrm{STZ}+\mathrm{TQ}) .{ }^{*} p<0.05$ (significant difference of between DC vs. NC), ${ }^{\#} p<0.05$ (significant difference between DC vs. STZ + TQ).

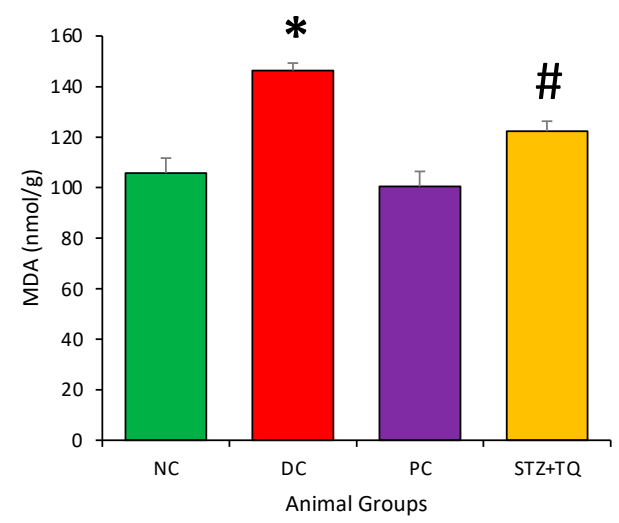

Figure 7. The lipid peroxidation, MDA level in different groups of rats after 8 weeks continued treatment. The experimental animals were uniformly divided into each group ( $n=8$ per group). Data are means \pm standard error of the mean (SEM). Groups: Normal control (NC); disease control (DC) i.e., STZ-treated group; positive control (PC) animal treated with STZ and Glibenclamide; diabetic rats treated with TQ $(\mathrm{STZ}+\mathrm{TQ}) .{ }^{*} p<0.05$ (significant difference of between DC vs. NC), ${ }^{*} p<0.05$ (significant difference between DC vs. STZ + TQ).

\subsection{TQ Decreases the Creatinine and Urea Level in STZ-Treated Diabetic Rats}

Urea and creatinine were measured in serum of all experimental rats. The results revealed that these parameters were significantly increased (urea as $35.9 \pm 1.8 \mathrm{mg} / \mathrm{dL}$ and creatinine as $98.7 \pm 7.8 \mu$ mole/L) in STZ-toxicated diabetic rats as compared to the control rats. In addition, the STZ-treated diabetic rats with TQ led to a considerable decrease (urea as $14.6 \pm 2.6 \mathrm{mg} / \mathrm{dL}$ and creatinine as $67.5 \pm 6.9 \mu \mathrm{mole} / \mathrm{L}$ ) in levels of these kidney function parameters (Figure 8). 

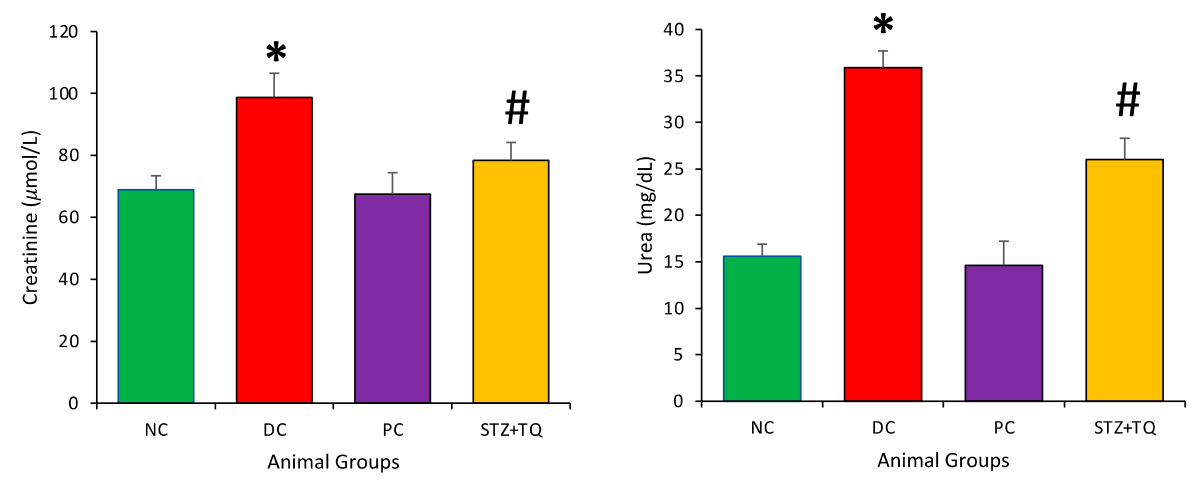

Figure 8. The kidney function test profile in different groups of rats after 8 weeks of follow up. Rats were uniformly divided into each group ( $n=8$ per group). Data are means \pm standard error of the mean (SEM). Groups: Normal control (NC); disease control (DC) i.e., STZ-treated group; positive control (PC) animal treated with STZ and Glibenclamide; diabetic rats treated with TQ (STZ + TQ). ${ }^{*} p<0.05$ (significant difference of between DC vs. NC), ${ }^{\#} p<0.05$ (significant difference between DC vs. STZ + TQ).

\subsection{Effect of Thymoquinone on Inflammatory Marker Levels in STZ-Treated Diabetic Rats}

Imbalance between the oxidative stress as well as antioxidant defense system is associated with the inflammatory response [23]. STZ-induced diabetic rats showed increased levels of pro-inflammatory markers such as C-reactive protein (CRP) $(0.91 \pm 0.07 \mathrm{ng} / \mathrm{mL})$, tumor necrosis factor- $\alpha$ (TNF- $\alpha)(48.64 \pm 2.3 \mathrm{pg} / \mathrm{mL})$, interleukin-6 (IL-6) $(103.64 \pm 3 \mathrm{pg} / \mathrm{mL})$, and interleukin-1 $\beta$ (IL-1 $\beta)(20.3 \pm 1.2 \mathrm{pg} / \mathrm{mL})$ in comparison to control $(p<0.05)$. The oral administration of TQ $(150 \mathrm{mg} / \mathrm{kg}$ b.w.) in STZ-induced diabetic rats for consecutive 8 weeks led to reduced inflammatory markers towards the normal levels (CRP as $0.72 \pm 0.05 \mathrm{ng} / \mathrm{mL}$, TNF- $\alpha$ as $38.29 \pm 1.3 \mathrm{pg} / \mathrm{mL}$, IL- 6 as $78.29 \pm 9 \mathrm{pg} / \mathrm{mL}$, and IL- $1 \beta$ as $18.10 \pm 1.4 \mathrm{pg} / \mathrm{mL}$ ), indicating the anti-inflammatory activities of TQ (Figure 9).

\subsection{TQ Treatment Alleviates Hepatocytes Changes in STZ-Treated Diabetic Rats}

The liver histology in the control group showed normal hepatocytes architecture and appropriate liver sinusoids. The diabetic liver sections from STZ-induced rat groups showed several changes including a degeneration and damage of hepatocytes, dilated sinusoids, infiltration of lymphocytes, and congestion. The histopathological examination of liver sections from the treatment group $(\mathrm{STZ}+\mathrm{TQ})$ showed preservation of hepatocyte structure, mild degeneration, hemorrhages, and infiltration of lymphocytes (Figure 10). 

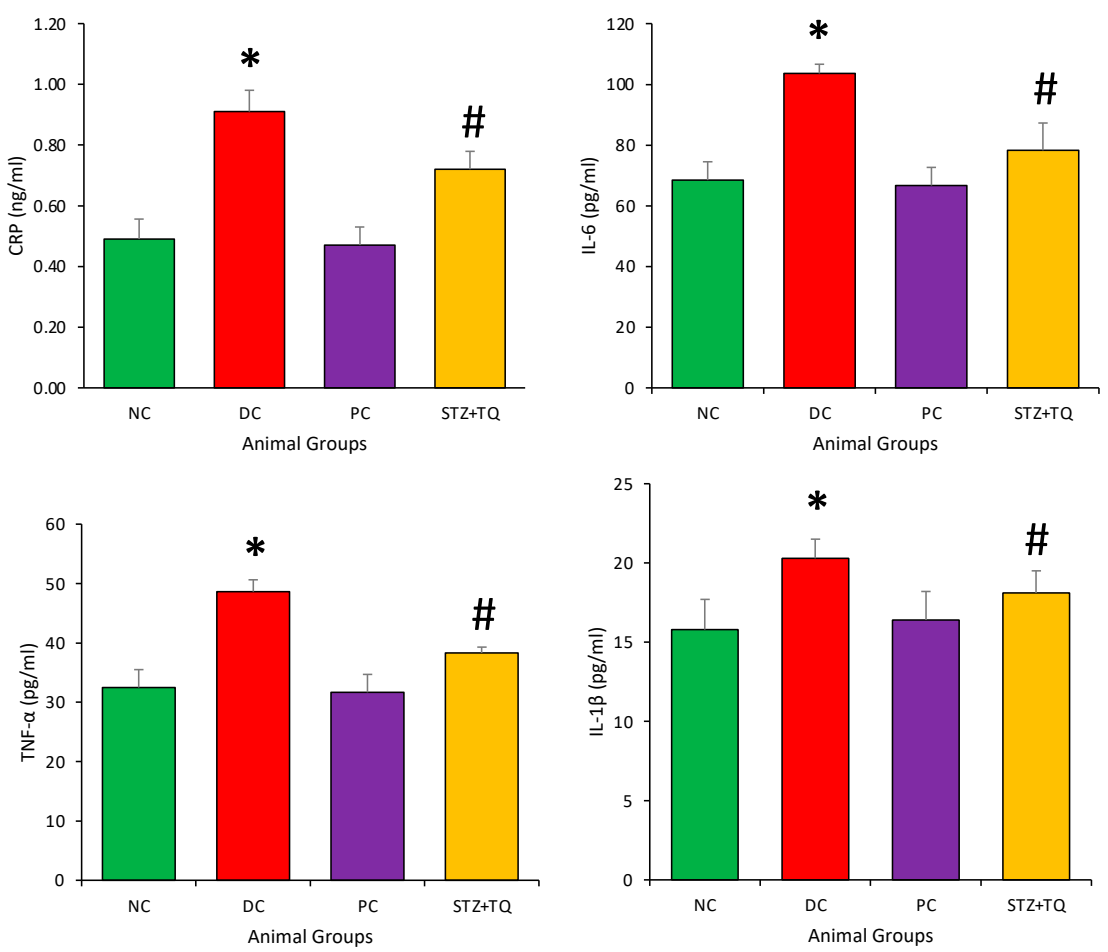

Figure 9. The inflammatory markers level in different groups of rats after 8 weeks of continues treatment. The experimental animals were uniformly divided into each group ( $n=8$ per group). Data are means \pm standard error of the mean (SEM). Groups: Normal control (NC); disease control (DC) i.e., STZ-treated group; positive control (PC) animal treated with STZ and Glibenclamide; diabetic rats treated with TQ $(\mathrm{STZ}+\mathrm{TQ}) .{ }^{*} p<0.05$ (significant difference of between DC vs. NC), ${ }^{*} p<0.05$ (significant difference between DC vs. STZ + TQ).
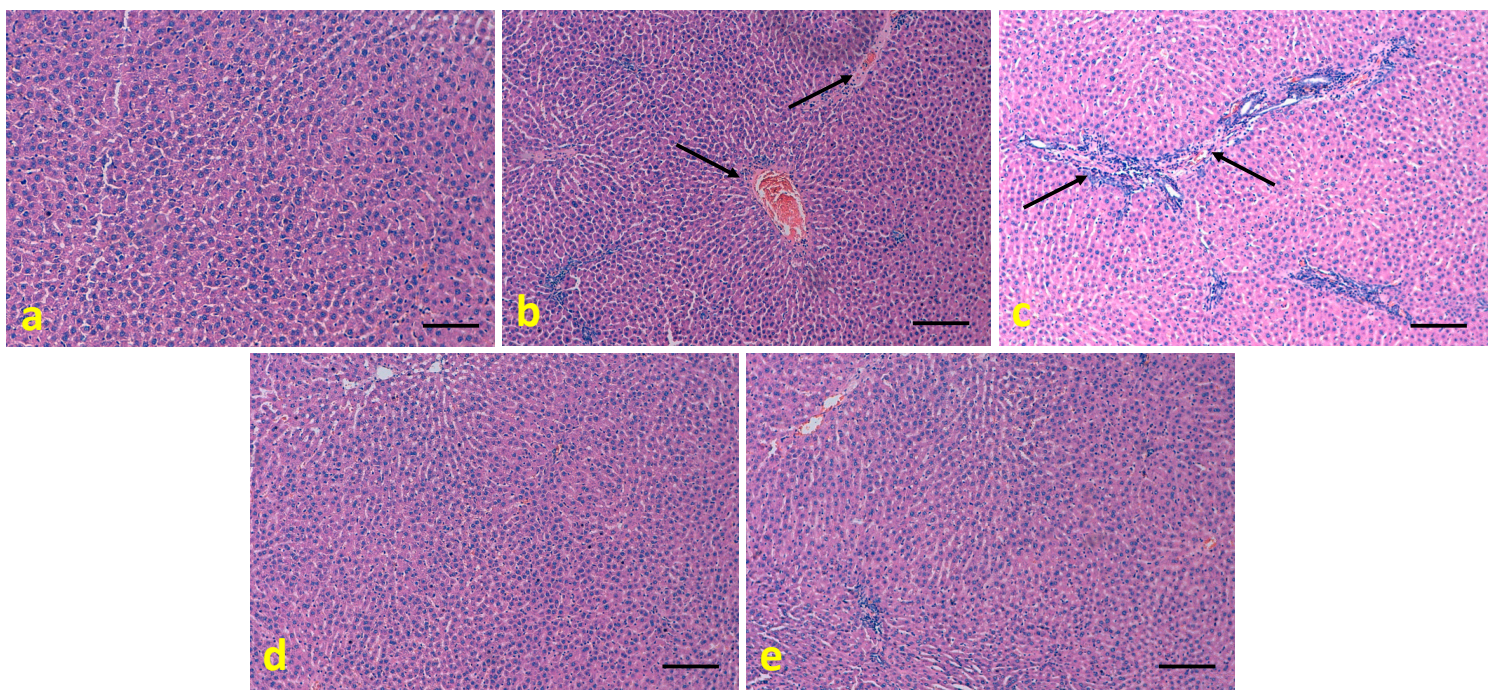

Figure 10. The role of TQ in the maintenance of liver architecture. (a) The normal morphology of hepatocytes was seen in normal control group. (b,c) The diabetic liver sections from STZ-induced rat groups showed congestion, hemorrhages, edema, and enhanced inflammatory cells. (d) The histopathological examination of liver sections from treatment group $(\mathrm{STZ}+\mathrm{TQ})$ showed preservation of hepatocyte structure, mild degeneration, hemorrhages, infiltration of lymphocytes. (e) Normal architecture of hepatocyte of PC group (Scale bar $=100 \mu \mathrm{m})$. 


\subsection{Effect of Thymoquinone on STZ-Induced Liver Fibrosis}

The lipid metabolism pathogenesis and high-level glucose play an important role in the pathogenesis of liver including formation of liver fibrosis. The Masson's trichrome staining was performed to determine the degree of fibrosis or accumulation of collagen. These sections were evaluated by two independent pathologists in a blinded manner. The degree of liver fibrosis was estimated using blue stain collagen area of Masson trichrome and five fields were selected per specimen. The results were presented as the percentage of fibrotic area in each field [26]. Criteria for scoring were as follows: score 0, normal; score 1, mild (small fibrous area); score 2, moderate (increased fibrosis); score 3, severe (large fibrous areas).

Masson's trichrome staining of liver tissue sections showed the effects of TQ on liver fibrosis in STZ-induced rats. The STZ-induced rat liver tissue sections showed noticeable collagen accumulation (Figure 11). Though, TQ treatment showed noteworthy reduction in the fibrosis in STZ-induced plus TQ administered rats. This finding revealed that TQ plays a significant role in the liver protection as evident by low collagen accumulation in the TQ treatment group.
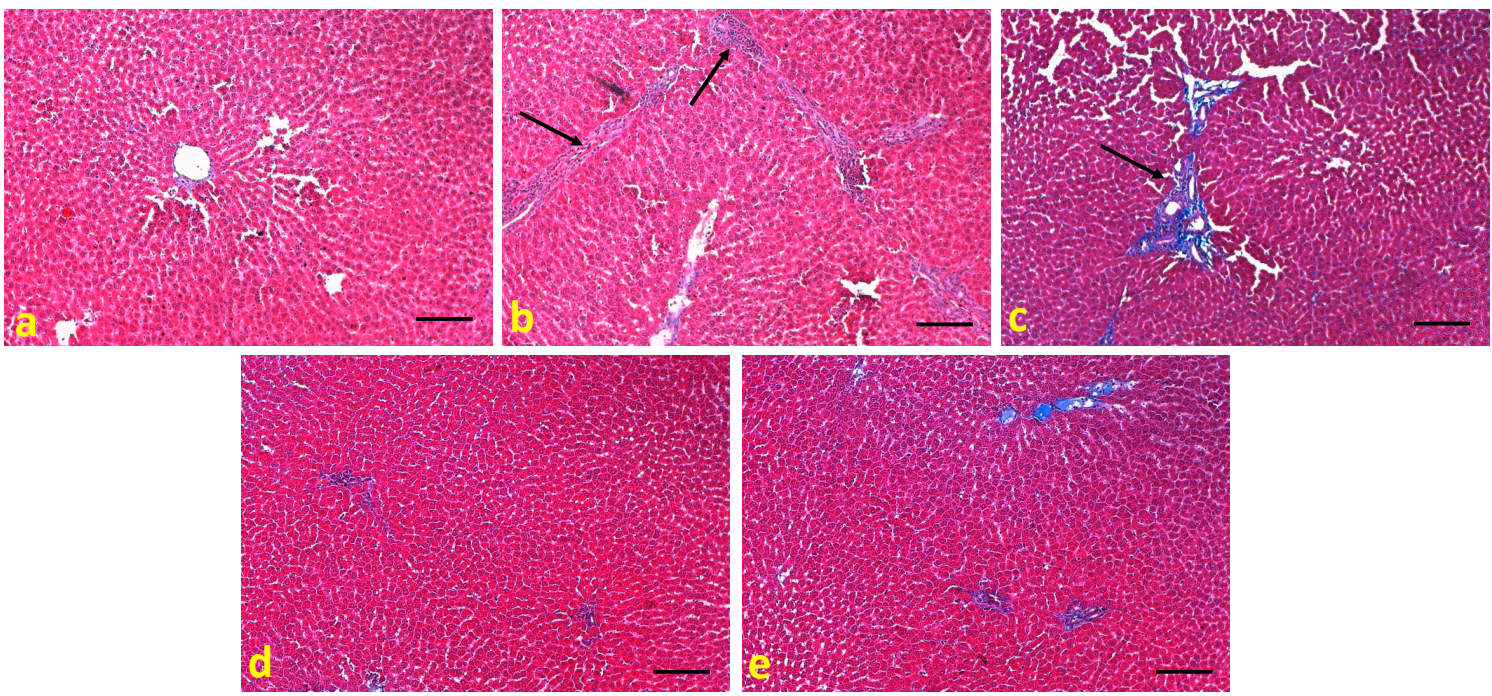

Figure 11. The collagen fiber was measured in all the experimental groups using Masson's trichrome staining. (a) Collagen fiber not observed in normal hepatocytes; $(\mathbf{b}, \mathbf{c})$ the collagen fiber was significantly higher in STZ-induced rats; (d) The TQ treatment in diabetic animal group showed reduction of collagen. (e) PC group only showing very low collagen fiber deposition (Scale bar $=100 \mu \mathrm{m})$.

\subsection{Role of Thymoquinone on Cox-2 Protein Expression in STZ-Treated Diabetic Rats}

The expression of Cyclooxygenase 2 (Cox-2) protein was analyzed in different experimental animals by using immunohistochemistry staining. The significantly high expression of COX2 protein was noticed in STZ-toxicated diabetic rats. Moreover, COX2 protein expression was decreased in STZ-induced plus TQ administered rats. However, the Cox-2 expression was not seen in the TQ only treated group. The expression pattern of Cox-2 among different animal groups was significant (Figure 12). 


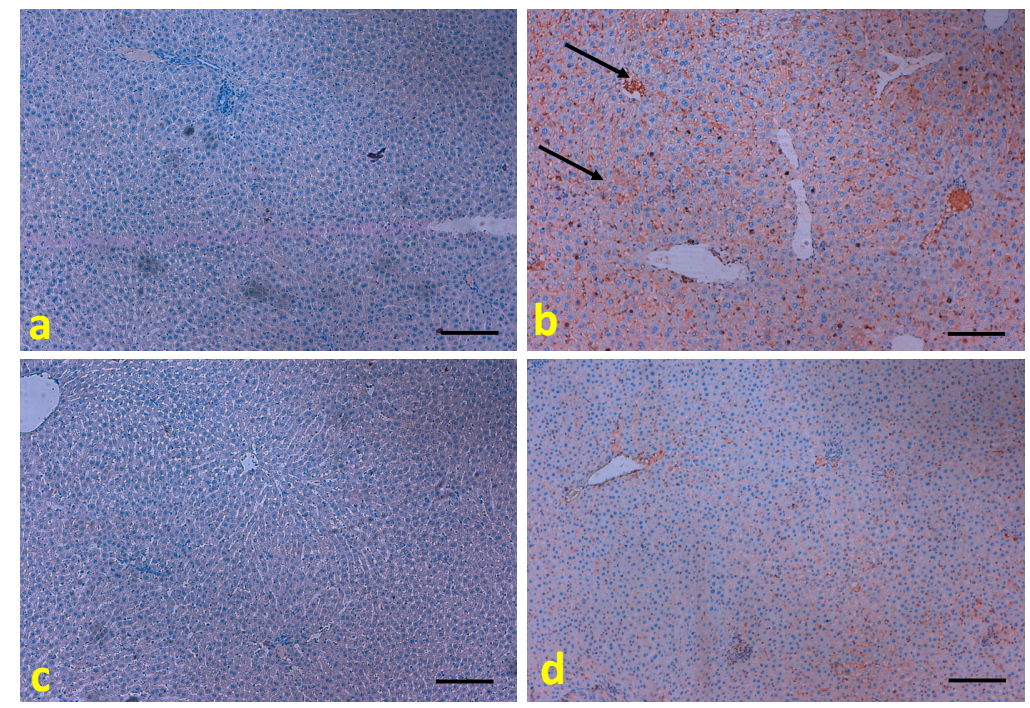

Figure 12. The Cox-2 protein expression was analyzed in different experimental groups. (a) The control animals did not show any expression; (b) The significantly high expression of Cox-2 protein was noticed in STZ-induced diabetic rats; (c) Cox-2 protein expression was diminished in STZinduced plus TQ administered rats; (d) PC group did not show any expression (Scale bar $=100 \mu \mathrm{m}$ ).

\section{Discussion}

The liver is primarily susceptible to the effects of hyperglycemia-induced oxidative stress [27]. Different mechanisms endorse the hepatocyte injury through inflammation and oxidative stress [28]. STZ is a diabetogenic and hepatotoxic material which damages the pancreatic beta-cell membrane, fragments DNA, and reacts with several enzymes including glucokinase, and significantly decreases the insulin levels [29]. In STZ-induced hyperglycemia in experimental models, it is important to study the role of anti-diabetic agents. In this study, TQ (50 mg/ $\mathrm{kg}$ b.w.) was given to the animals to evaluate its antidiabetic potential.

STZ-induced diabetes leads to loss of body weight, which may be due to muscle wasting [30]. In the current study, STZ caused a major weight loss of rats in the diabetic control group (19.93\%) in comparison to the normal control animals. Supplementation with TQ to the diabetic rats presented a remarkable diminishing effect on the percentage changes of body weight (11.04\%) as compared to the diabetic rats fed with just normal diet. Some previous studies are in accordance with the current finding, which also report that the body weights of the STZ-injected diabetic animals are reduced significantly. However, Nigella sativa oil treatment to such animals increased their body weights in comparison to diabetic non-treated rats [31]. The possible mechanism of TQ may play an important role in the maintenance of body weight or its increment through the prevention of loss of muscle mass in STZ-induced rats.

A high fasting glucose level is a key indicator in diabetic animals. The STZ-treated group presented increased blood glucose levels $(225 \pm 7 \mathrm{mg} / \mathrm{dL})$ as compared to the animals in the control group $(94 \pm 5 \mathrm{mg} / \mathrm{dL})$. STZ-induced diabetic animals treated with TQ showed decreased blood glucose levels (146 $\pm 7 \mathrm{mg} / \mathrm{dL}$ ). Some previous reports show that there was a gradual enhancement in blood glucose level due to the administration of STZ and blood glucose concentration is lowered by TQ treatment [32]. Hyperglycemia in STZ diabetic rats results from STZ-induced damage of the pancreatic $\beta$-cells, decreased secretion of insulin and its sensitivity, decreased overall glucose uptake, and also increased glucose production in the liver [33,34]. A study reported that thymoquinone ameliorates chemical induced oxidative stress and $\beta$-cell damage in experimental hyperglycemic rats [35]. The meta-analysis examined by some previous studies evaluated the serum glucose (SG) level or serum insulin level or body weight (BW). In those studies, it has been observed an overall pooled standardized mean difference (SMD) of $-9.176 \mathrm{mg} / \mathrm{dL}$. 
The TQ decreased the SG level (-9.176 mg/dL) significantly in the STZ-induced diabetic models. Moreover, a meta-analysis of the effect of TQ on body weight revealed that TQ has a significant effect on the body weight of diabetic animals. In addition, the overall pooled estimate of the level of serum insulin was significant with SMD of 1.681 [36].

Nigella sativa has been shown to significantly improve clinical parameters like hyperglycemia, with a significant fall in fasting blood glucose, blood glucose level $2 \mathrm{~h}$ postprandial, glycated hemoglobin, and insulin resistance, and a rise in serum insulin [37].

The treatment of the STZ diabetic animals with TQ caused improved blood glucose and insulin secretion indicating that TQ is an effective anti-hyperglycemic agent.

Diabetic mellitus is mainly associated with multiple metabolic disorders, among which lipid metabolism is comparatively affected resulting in higher concentrations of TG and TC and low levels of HDL-cholesterol [38]. In the current study, TC (139.37 $\pm 8.7 \mathrm{mg} / \mathrm{dL})$, TG $(238.7 \pm 7.2 \mathrm{mg} / \mathrm{dL})$, LDL-cholesterol $(167.9 \pm 7.2 \mathrm{mg} / \mathrm{dL})$ levels were significantly increased and HDL-cholesterol decreased $(38.6 \pm 7.2 \mathrm{mg} / \mathrm{dL})$ in STZ-treated diabetic rats. The treatment with TQ caused a significant reduction of TC (117.23 $\pm 4.7 \mathrm{mg} / \mathrm{dL})$, TG $(201.23 \pm 9.4 \mathrm{mg} / \mathrm{dL})$, LDL-cholesterol levels $(132.3 \pm 9.4 \mathrm{mg} / \mathrm{dL})$. Moreover, the decreased serum HDL-cholesterol in diabetic animals was also upturned toward the normal level $(61.9 \pm 9.4 \mathrm{mg} / \mathrm{dL})$ after the treatment with TQ. Previous findings were in accordance with the current results and it was demonstrated that a significant decline in serum triglyceride levels in diabetic animals treated by TQ [39] and Nigella sativa significantly decreased LDL-lipoproteins [40]. TQ administration decreases protein carbonyls and serum level of TC, LDL-C, TG, and MDA through decreasing the oxidative stress. TQ also improves the activity of arylesterase accompanied by decrease in the activity of HMG-CoA reductase [41].

STZ induces experimental diabetes in rats [42], thereby producing elevated levels of liver function enzymes ALT, AST, and ALP and this is a good indicator of liver damage. ALT and AST are directly linked with the reaction of amino acids to keto acids and are designated to increase in diabetic conditions [43]. The present study demonstrated the increased activities of serum liver function enzymes, ALT (187.5 $\pm 9.0 \mathrm{U} / \mathrm{L})$, AST $(194.6 \pm 3.0 \mathrm{U} / \mathrm{L}), \operatorname{ALP}(153.2 \pm 3.0 \mathrm{U} / \mathrm{L})$ level, designated that hepatotoxicity might be due to induction of hyperglycemia via STZ induction. The current finding reported that the treatment of STZ -treated diabetic rats with TQ leads to a substantial reduction in levels of liver function enzymes, ALT (120.5 $\pm 8.0 \mathrm{U} / \mathrm{L})$, AST (139.3 $\pm 9.0 \mathrm{U} / \mathrm{L})$, ALP $(112.6 \pm 9.0 \mathrm{U} / \mathrm{L})$ towards normal levels that evidences that TQ protect liver cells. Previous finding demonstrated that beneficial effects of thymoquinone on hepatic key enzymes in diabetic rats [44]

Lipid peroxidation provides a sign of cellular damage mediated through ROS [45]. The high levels of ROS causes membrane lipid peroxidation in addition to the production of malondialdehyde (MDA). Liver MDA levels were significantly higher in STZ-induced rats and it was also observed that TQ supplementation significantly decreased the hepatic lipid peroxidation.

Inflammation play an important role in diabetes development and is thus associated with enhanced insulin resistance and reduced response in insulin target tissues [46]. Moreover, NF-k $\beta$ and TNF- $\alpha$ are vital indicators of insulin resistance and pancreatic $\beta$-cells dysfunction, causative to the development of diabetes mellitus [47]. The circulating levels of the most proinflammatory cytokines are usually elevated in diabetes mellitus, mainly as a result of hyperglycemia, which stimulate the blood levels of cytokines to increase through an oxidative mechanism $[48,49]$. Previous reports based on in vivo and in vitro based studies reported that TQ plays a role in the reduction of pro-inflammatory cytokines such as IL-6, Cox-2, and TNF- $\alpha[50,51]$. In this study, we reported that TQ inhibited the overproduction of inflammatory cytokines in STZ-treated diabetic animals because of its the anti-inflammatory responses.

The actual mechanism of STZ-treated diabetes in rats primarily involves ROS production, DNA alkylation, and overproduction of nitric oxide (NO) in pancreatic $\beta$-cells [42]. The loss of $\beta$-cell mass as well as its function is the main reason of the development of 
DM and causes B cell dysfunction [52,53]. In such circumstances, pancreatic $\beta$-cells insulin production becomes less controlled and leads to elevation of the postprandial glucose level above the normal range [54]. The enhanced oxidative stress found in diabetic animals lead to autoxidation of glucose, protein glycation, lipid peroxidation, and low activities of antioxidant enzymes [55].

In accordance with this study, the current study demonstrates that increased lipid peroxidation and diminished actions of antioxidant enzymes, including SOD, GPx, and GST, were noticed in livers of the STZ-treated diabetic rats. The activities of antioxidants enzymes increased in the STZ + TQ group and restored enzyme activities towards the normal value. This finding evidently showed that that TQ plays a vital role as hepatoprotective against STZ-induced diabetic animals, primarily by employing its antioxidant properties. In accordance with current study, previous finding reported that administration of Nigella sativa oil to the diabetic animals meaningfully elevated the hepatic and pancreatic catalase and GSH activities in comparison to the diabetic control animals [31]. Besides, thymoquinone improved insulin secretion and reduced oxidative stress in diabetic rats [31].

In experimental diabetes, STZ exerts its destructive effects on liver and pancreatic $\beta$-cells by causing an enhancement in the size of the hepatocytes and in their nuclei [56]. The present study suggest that TQ has a protective potential in the liver injury caused by STZ-induced diabetes. Some previous studies have reported that liver histological observations in Nigella sativa-treated rats expressed normal liver tissue architecture displaying the lobules with the central vein as its center and peripheral portal tracts [31]. Mechanisms of TQ involved in hepatocytes protection were examined and it was noticed that the TQ plays a significant function in the inflammatory response. The current study reported that TQ decreased the Cox-2 protein expression in STZ-induced plus TQ administered rats, which explains that TQ has ability to decrease the liver injury mediated by STZ. The previous study based on TQ also reported that Cox-2 protein expression in Schwann cells or sciatic nerve was decreased by TQ and the mechanism may be involved through the regulation of the inflammatory reaction [51]. Besides, another study reported that Nigella sativa and its active compound thymoquinone decreases cyclooxygenase- 2 activity and oxidative stress in pancreatic tissue of diabetic rats [57].

\section{Conclusions}

In conclusion, TQ demonstrates the anti-diabetic, anti-inflammatory, and hepatoprotective effects through the regulation of blood glucose, lipid profile, besides improving the liver functions and oxidative stress status. In addition, this novel compound from black seeds reduces the histopathological changes by decreasing the injury in hepatocyte architecture as compared to the diabetic control animals through its antioxidant and antiinflammatory activity. In this study, we have demonstrated for the first time the role of TQ in the reduction of the expression of cyclooxygenase- 2 and fibrosis formation in diabetic animal models. Overall, thymoquinone ameliorates most of the changes which are observed in diabetic animals and efficiently manages the damages induced by STZ. The in depth molecular mechanism of thymoquinone in the management of diabetes needs to be explored properly.

Author Contributions: Conceptualization, S.A.A. and A.H.R.; methodology, S.A.A., A.H.R., A.M.A., A.A.K.; validation, S.A.A., A.H.R., A.M.A., A.A.K.; M.A.A.; resources, M.A.A.; data curation, A.H.R. and A.A.K.; writing-original draft preparation, A.H.R., S.A.A. and A.A.K.; writing-review and editing, A.M.A. and M.A.A.; supervision, S.A.A., M.A.A., and A.M.A.; All authors have read and agreed to the published version of the manuscript.

Funding: This work was funded and supported by Deanship of Scientific Research, Qassim University, and Grants No. CAMS1-2019-2-2-I-5623.

Institutional Review Board Statement: The study was conducted according to the guidelines of the Declaration of Helsinki, and approved by the Ethical Committee (2019-2-2-I-5623), CAMS, Qassim University. 
Informed Consent Statement: Not applicable.

Data Availability Statement: The data used to support the findings of this study are included within the article.

Conflicts of Interest: The authors declare no conflict of interest.

\section{References}

1. Arumugam, G.; Manjula, P.; Paari, N. A review: Anti diabetic medicinal plants used for diabetes mellitus. J. Acute Dis. 2013, 2, 196-200. [CrossRef]

2. Zhu, B.; Wu, X.M.; Bi, Y.F.; Yang, Y. Effect of bilirubin concentration on the risk of diabetic complications: A meta-analysis of epidemiologic studies. Sci. Rep. 2017, 7, 41681. [CrossRef] [PubMed]

3. World Health Organization. Definition, Diagnosis and Classification of Diabetes Mellitus and Its Complications; Department of Noncommunicable Disease Surveillance: Geneva, Switzerland, 1999.

4. Holman, N.; Young, B.; Gadsby, R. Current prevalence of Type 1 and Type 2 diabetes in adults and children in the UK. Diabet Med. 2015, 32, 1119-1120. [CrossRef] [PubMed]

5. Natali, A.; Ferrannini, E. Effects of metformin and thiazolidinediones on suppression of hepatic glucose production and stimulation of glucose uptake in type 2 diabetes: A systematic review. Diabetologia 2006, 49, 434-441. [CrossRef] [PubMed]

6. Holt, R.I.G. Textbook of Diabetes, 4th ed.; Wiley-Blackwell: Chichester, West Sussex, UK; Hoboken, NJ, USA, $2010 ;$ p. 1119.

7. Pheiffer, C.; Pillay-van Wyk, V.; Joubert, J.D.; Levitt, N.; Nglazi, M.D.; Bradshaw, D. The prevalence of type 2 diabetes in South Africa: A systematic review protocol. BMJ Open 2018, 8, e021029. [CrossRef]

8. Hashemnia, M.; Nikousefat, Z.; Yazdani-Rostam, M. Antidiabetic effect of Pistacia atlantica and Amygdalus scoparia in streptozotocin-induced diabetic mice. Comp. Clin. Pathol. 2015, 24, 1301-1306. [CrossRef]

9. Almatroodi, S.A.; Alsahli, M.A.; Alharbi, H.M.; Khan, A.A.; Husain Rahmani, A. Epigallocatechin-3-Gallate (EGCG), An Active Constituent of Green Tea: Implications in the Prevention of Liver Injury Induced by Diethylnitrosamine (DEN) in Rats. Appl. Sci. 2019, 9, 4821. [CrossRef]

10. Prabhakar, P.K.; Kumar, A.; Doblec, M. Combination therapy: A new strategy to manage diabetes and its complications. Phytomedicine 2014, 21, 123-130. [CrossRef]

11. Zhang, Y.J.; Gan, R.W.; Li, S.; Zhou, Y.; Li, A.; Xu, D.; Li, H. Antioxidant phytochemicals for the prevention and treatment of chronic diseases. Molecules 2015, 20, 21138-21156. [CrossRef]

12. Al-Bukhari, M. Sahi Al-Bukhari, the Collection of Authentic Sayings of Prophet Mohammad (Peace Be Upon Him), 2nd ed.; Division 71 on Medicine; Hilal Yayinlari: Ankara, Turkey, 1976.

13. Agbaria, R.; Gabarin, A.; Dahan, A.; Ben-Shabat, S. Anticancer activity of Nigella sativa (black seed) and its relationship with the thermal processing and quinone composition of the seed. Drug Des. Devel. Ther. 2015, 9, 3119-3124.

14. Darakhshan, S.; Bidmeshki Pour, A.; Hosseinzadeh Colagar, A.; Sisakhtnezhad, S. Thymoquinone and its therapeutic potentials. Pharmacol. Rev. 2015, 95-96, 138-158. [CrossRef]

15. Barakat, E.M.; El Wakeel, L.M.; Hagag, R.S. Effects of Nigella sativa on outcome of hepatitis C in Egypt. World J. Gastroenterol. 2013, 19, 2529-2536. [CrossRef]

16. Rahmani, A.H.; Alzohairy, M.A.; Khan, M.A.; Aly, S.M. Therapeutic implications of black seed and its constituent thymoquinone in the prevention of cancer through inactivation and activation of molecular pathways. Evid. Based Complement. Alternat. Med. 2014, 2014, 724658. [CrossRef] [PubMed]

17. Gupta, R.; Sharma, A.K.; Dobhal, M.P.; Sharma, M.C.; Gupta, R.S. Antidiabetic and antioxidant potential of $\beta$-sitosterol in Streptozotocin-induced experimental hyperglycemia. J. Diabetes. 2011, 3, 29-37. [CrossRef]

18. Cheng, D.; Liang, B.; Li, Y. Antihyperglycemic effect of Ginkgo biloba extract in streptozotocin-induced diabetes in rats. BioMed Res. Int. 2013, 2013, 162724. [CrossRef] [PubMed]

19. Sayed, A.A. Thymoquinone and proanthocyanidin attenuation of diabetic nephropathy in rats. Eur. Rev. Med. Pharmacol. Sci. 2012, 16, 808-815. [CrossRef]

20. Abukhader, M.M. The effect of route of administration in thymoquinone toxicity in male and female rats. Indian J. Pharm. Sci. 2012, 74, 195-200. [CrossRef] [PubMed]

21. Al-Ali, A.; Alkhawajah, A.A.; Randhawa, M.A.; Shaikh, N.A. Oral and intraperitoneal LD50 of thymoquinone, an active principle of Nigella sativa, in mice and rats. J. Ayub. Med. Coll. Abbottabad. 2008, 20, 25-27. [PubMed]

22. Nayak, S.S.; Pattabiraman, T.N. A new calorimetric method for the estimation of glycosylated haemoglobin. Clin. Chim. Acta 1981, 109, 267-274. [CrossRef]

23. Garcia, Y.J.; Rodriguez-Malaver, A.J.; Penaloza, N. Lipid peroxidation measurement by thiobarbituric acid assay in rat cerebellar slices. J. Neurosci. Methods 2005, 144, 127-135. [CrossRef]

24. Babiker, A.Y.; Rahmani, A.H.; Abdalaziz, M.S.; Albutti, A.; Aly, S.M.; Ahmed, H.G. Expressional analysis of p16 and cytokeratin19 protein in the genesis of oral squamous cell carcinoma patients. Int. J. Clin. Exp. Med. 2014, 7, 1524-1530. [PubMed]

25. Rahmani, A.H.; Ababiker, A.Y.; Alsahli, M.A.; Almatroodi, S.A.; Husain, N.E.O.S. Prognostic Significance of Vascular Endothelial Growth Factor (VEGF) and Her-2 Protein in the Genesis of Cervical Carcinoma. Open Access Maced. J. Med. Sci. 2018, 6, 263-268. [CrossRef] 
26. Feriani, A.; del Mar Contreras, M.; Talhaoui, N.; Gómez-Caravaca, A.M.; Taamalli, A.; Segura-Carretero, A.; Ghazouani, L.; El Feki, A.; Allagui, M.S. Protective effect of Globularia alypum leaves against deltamethrin-induced nephrotoxicity in rats and determination of its bioactive compounds using high-performance liquid chromatography coupled with electrospray ionization tandem quadrupole-time-of-flight mass spectrometry. J. Funct. Foods 2017, 32, 139-148.

27. Palsamy, P.; Sivakumar, S.; Subramanian, S. Resveratrol attenuates hyperglycaemia-mediated oxidative stress, pro-inflammatory cytokines and protects hepatocytes ultrastructure in streptozotocin-nicotinamide-induced experimental diabetic rats. Chem. Biol. Interact. 2010, 186, 200-210. [CrossRef] [PubMed]

28. Garcia-Compean, D.; Jacquez-Quintana, J.O.; Gonzalez-Gonzalez, J.A.; Maldonado-Garza, H. Liver cirrhosis and diabetes: Risk factors, pathophysiology, clinical implications and management. World J. Gastroenterol. 2009, 15, 280-288. [CrossRef]

29. Perfumi, M.; Arnold, N.; Tacconi, R. Hypoglycemic activity of Salvia fruticosa Mill. J. Ethnopharmacol. 1991, 23, 135-140. [CrossRef]

30. Swanston-Flatt, S.K.; Day, C.; Bailey, C.J.; Flatt, P.R. Traditional plant treatment for diabetes: Studies in normal and streptozotocin diabetic mice. Diabetologia 1990, 33, 462-464. [CrossRef] [PubMed]

31. Abdelrazek, H.M.A.; Kilany, O.E.; Muhammad, M.A.A.; Tag, H.M.; Abdelazim, A.M. Black Seed Thymoquinone Improved Insulin Secretion, Hepatic Glycogen Storage, and Oxidative Stress in Streptozotocin-Induced Diabetic Male Wistar Rats. Oxid. Med. Cell. Longev. 2018, 2018, 10. [CrossRef]

32. Sangi, S.M.A.; Sulaiman, M.I.; El-wahab, M.F.A.; Ahmedani, E.I.; Ali, S.S. Antihyperglycemic effect of thymoquinone and oleuropein, on streptozotocin-induced diabetes mellitus in experimental animals. Pharmacogn. Mag. 2015, 11 (Suppl. 2), S251-S257. [CrossRef]

33. Beck-Nielsen, H. Insulinresistens: Organmanifestationer og cellulaere mekanismer. Ugeskr. Laeger 2002, 164, $2130-2135$.

34. Gold, A.H. The effect of diabetes and insulin on liver glycogen synthetase activation. J. Biol. Chem. 1970, 245, 903-905. [CrossRef]

35. Sankaranarayanan, C.; Pari, L. Thymoquinone ameliorates chemical induced oxidative stress and $\beta$-cell damage in experimental hyperglycemic rats. Chem. Biol. Interact. 2011, 190, 148-154. [CrossRef]

36. Bule, M.; Nikfar, S.; Amini, M.; Abdollahi, M. The antidiabetic effect of thymoquinone: A systematic review and meta-analysis of animal studies. Food Res. Int. 2020, 127, 108736. [CrossRef] [PubMed]

37. Hamdan, A.; Haji Idrus, R.; Mokhtar, M.H. Effects of nigella sativa on type-2 diabetes mellitus: A systematic review. Int. J. Environ. Res. Public Health 2019, 16, 4911. [CrossRef] [PubMed]

38. Elberry, A.A.; Harraz, F.M.; Ghareib, S.A.; Gabr, S.A.; Nagy, A.A.; Abdel-Sattar, E. Methanolic extract of Marrubiumvulgare ameliorates hyperglycemia and dyslipidemia in streptozotocin-induced diabetic rats. Int. J. Diabetes Mellitus. 2011, 11, 1877-1878.

39. Fararh, K.M.; Ibrahim, A.K.; Elsonosy, Y.A. Thymoquinone enhances the activities of enzymes related to energy metabolism in peripheral leukocytes of diabetic rats. Res. Vet. Sci. 2010, 88, 400-404. [CrossRef]

40. Asgary, S.; Sahebkar, A.; Goli-Malekabadi, N. Ameliorative effects of Nigella sativa on dyslipidemia. J. Endocrinol. Investig. 2015, 38, 1039-1046. [CrossRef] [PubMed]

41. Farkhondeh, T.; Samarghandian, S.; Borji, A. An overview on cardioprotective and anti-diabetic effects of thymoquinone. Asian Pac. J. Trop. Med. 2017, 10, 849-854. [CrossRef] [PubMed]

42. Szkudelski, T. The mechanism of alloxan and streptozotocin action in B cells of the rat pancreas. Physiol. Res. 2001, 50, 537-546. [PubMed]

43. Kawai, T. Clinical Aspects of the Plasma Proteins; Central Clinical Laboratory and Research Division Nihon University Surugadai Hospital: Tokyo, Japan, 1974.

44. Pari, L.; Sankaranarayanan, C. Beneficial effects of thymoquinone on hepatic key enzymes in streptozotocin-nicotinamide induced diabetic rats. Life Sci. 2009, 85, 830-834. [CrossRef]

45. Marnett, L.J. Lipid peroxidation-DNA damage by malondialdehyde. Mutat. Res. 1999, 424, 83-95. [CrossRef]

46. Duncan, B.B.; Schmidt, M.I.; Pankow, J.S.; Ballantyne, C.M.; Couper, D.; Vigo, A.; Hoogeveen, R.; Folsom, A.R.; Heiss, G. Low-grade systemic inflammation and the development of type 2 diabetes: The atherosclerosis risk in communities study. Diabetes 2003, 52, 1799-1805. [CrossRef]

47. Chen, F. Is NF-kappaB a culprit in type 2 diabetes? Biochem. Biophys. Res. Commun. 2005, 332, 1-3. [CrossRef] [PubMed]

48. Esposito, K.; Nappo, F.; Marfella, R.; Giugliano, G.; Giugliano, F.; Ciotola, M.; Quagliaro, L.; Ceriello, A.; GiuGliano, D. Inflammatory cytokine concentrations are acutely increased by hyperglycemia in humans: Role of oxidative stress. Circulation 2002, 106, 2067-2072. [CrossRef] [PubMed]

49. Ling, P.R.; Smith, R.J.; Bistrian, B.R. Hyperglycemia enhances the cytokine production and oxidative responses to a low but not high dose of endotoxin in rats. Crit. Care Med. 2005, 33, 1084-1089. [CrossRef]

50. Chen, L.; Li, B.; Chen, B.; Shao, Y.; Luo, Q.; Shi, X.; Chen, Y. Thymoquinone alleviates the experimental diabetic peripheral neuropathy by modulation of inflammation. Sci. Rep. 2016, 6, 1-11. [CrossRef]

51. Ikhsan, M.; Hiedayati, N.; Maeyama, K.; Nurwidya, F. Nigella sativa as an anti-inflammatory agent in asthma. BMC Res. Notes 2018, 11, 8. [CrossRef] [PubMed]

52. Lei, H.; Han, J.; Wang, Q.; Guo, S.; Sun, H.; Zhang, X. Effects of sesamin on streptozotocin (STZ)-induced NIT-1 pancreatic $\beta$-cell damage. Int. J. Mol. Sci. 2012, 13, 16961-16970. [CrossRef]

53. Porte, D.; Kahn, S.E. Beta-cell dysfunction and failure in type 2 diabetes: Potential mechanisms. Diabetes 2001, 50 (Suppl. 1), S160-S163. [CrossRef] [PubMed] 
54. White, M.G.; Shaw, J.A.; Taylor, R. Type 2 diabetes: The pathologic basis of reversible $\beta$-cell dysfunction. Diabetes Care 2016, 39, 2080-2088. [CrossRef]

55. Giugliano, D.; Ceriello, A.; Paolisso, G. Oxidative stress and diabetic vascular complications. Diabetes Care 1996, 19, 257-267. [CrossRef] [PubMed]

56. Welt, K.; Weiss, J.; Martin, R.; Dettmer, D.; Hermsdorf, T.; Asayama, K.; Meister, S.; Fitzl, G. Ultrastructural, immunohistochemical and biochemical investigations of the rat liver exposed to experimental diabetes und acute hypoxia with and without application of Ginkgo extract. Exp. Toxicol. Pathol. 2004, 55, 331-345. [CrossRef] [PubMed]

57. Al Wafai, R.J. Nigella sativa and thymoquinone suppress cyclooxygenase-2 and oxidative stress in pancreatic tissue of streptozotocin-induced diabetic rats. Pancreas 2013, 42, 841-849. [CrossRef] [PubMed] 